much darker than the cores, variations due to varying $\mathrm{Fe}$ and $\mathrm{Mg}$ contents.

A second generation of light green tourmalines also occurs in quartz veins of Quartzite. These are alkalideficient, Cr- and V-bearing tourmalines with higher $\mathrm{Mg} \#$ than those of the schorl-dravite series. The occupancy of the X-site, according to X-ray fluorescence data, is $\delta_{0,51} \mathrm{Ca}_{0.33} \mathrm{Na}_{0.15}$, thus corresponding to foitite, considered as an alkali-deficient schorl.

Raman studies also discriminated two groups of tourmalines, one belonging to the buerguerite-schorl series and the other to the dravite-buerguerite-uvite series.

Stable isotope data allowed to define sediment and hydrothermal waters as fluid sources, ruling out the association of the tourmalines with e.g. the Brasiliano granitoid bodies found in the area. $\delta^{18} \mathrm{O}$ compositions for tourmalines (+12 per mil) and host metachert and quartz veins $(+13$ per mil) are very similar, showing fluid equilibration during (re)crystallization of quartz and tourmaline.

The presence of at least two distinct groups of tourmalines indicates distinct environments and timing for tourmaline generation. In Tapera Grande, tourmalines were formed in a submarine exhalative-sedimentary environment. Their composition was not strongly affected by medium-grade metamorphism.

In Quartzite, tourmaline compositions reflect that of the country rock, once fluid percolation along Sertãozinho fault and associated fractures caused leaching of $\mathrm{Cr}$ (and V) and the crystallization of alkali-deficient, $\mathrm{Cr}$ (V-)bearing tourmalines in veins, together with quartz. The heat source for mineralizing fluids must have been a granitoid body (Pau Pedra) south of Tapera Grande and intermediate to acid pipes in the Quartzito area. These fluids were also responsible for distinct types of mineralization, characterized in Tapera Grande by the assemblage gold-pyrite-pyrrhotite-chalcopyrite, and in Quartzite by electrum-pyrite-chalcopyrite-sphaleritegalena-scheelite-molibdenite. — (December 14, 2001 ).

\section{A BONE FRAGMENT OF A PROBABLE AQUATIC VER- TEBRATE IN THE SERRA ALTA FORMATION (UPPER PERMIAN OF PARANÁ BASIN)}

Jorge HACHIRO $^{1}$, PAUlo C.F. GianNini ${ }^{1}$ AND

RENATA N. KINJO2

${ }^{1}$ Departamento de Geologia Sedimentar e Ambiental - IGc / USP.

${ }^{2}$ Programa de Graduação em Geologia do Instituto de Geociências da USP - IGc / USP
Presented by ANTONIO C. Rocha-CAMPos

We have found a robust bone fragment $(4 \mathrm{~cm}$ long; $2.5 \mathrm{~cm}$ in average diameter) in a suspension deposit of the Serra Alta Formation, Upper Permian of the Paraná Basin, along the Castelo Branco highway near Cesário Lange (SP). The bone expands towards one end with longitudinal protuberances and has fine superficial striae. The fossil-bearing sediments comprise submetric and metric beds of dark-gray siltstone with centimetric intercalations of dirty carbonate exhibiting bioturbation, coprolites and fossil remains (hardgrounds).

This skeletal fragment is interpreted as probably part of a posterior (bones: tibia; fibula; femur) or anterior (bones: radius; ulna; humerus) limb of an aquatic reptile or amphibian or, possibly, as a portion of the fin of a crossopterygian fish.

On the basis of thin sections of transverse cuts of the bone, it was possible to observe the original phosphatic nature (with low birefringence, concentric lamellae, negative elongation, and wavy extinction) and structure of the submilimetric and milimetric pore-canals filled by microcrystalline silica, as well as subordinate calcite cement.

This bone fragment was preserved due to the relative anoxic depositional conditions of the Serra Alta Sea, the low hydrodynamic energy of sedimentation, and the presence of alkaline fluids during early diagenesis which filled bone voids, mainly its pore-canal system with $\mathrm{CaCO}_{3}$.

The fragment is massive but slightly broken at both ends. Its massive nature contrasts with the much smaller and more fragile bones of mesosaurids of the subjacent Irati Subgroup (the most stagnant palaeoenvironment of Paraná Basin). Its body may have reached around $1.5 \mathrm{~m}$, in length, making it perhaps the largest aquatic organism of its time. If it was carnivorous, it would have been a considerable threat to the other animals of the Serra Alta Sea. - (December 14, 2001 ) .

\section{HEAVY METALS IN CONTAMINATED SOILS - SEQUENTIAL EXTRACTIONS}

\section{JANAINA F. MARQUES ${ }^{1}$ AND RAPHAEL HyPOLITO ${ }^{2}$}

${ }^{1}$ Programa de Pós-graduação em Hidrogeologia, Instituto de Geociências - USP, São Paulo, SP.

${ }^{2}$ Departamento de Geologia Sedimentar e Ambiental, Instituto de Geociências - USP, São Paulo, SP.

Presented by Antonio C. Rocha-Campos

In order to understand the mechanisms of contamination by metals, it is necessary to know the ways in which 